become established as a valuable aid to creating the desired atmosphere in both sound and television broadcasts, and sometimes as the centre feature of a programme.

\section{Specifications and Criteria for Biochemical Compounds}

Specifications and Criteria for Biochemical Compounds was published in 1960, and contained information on 113 compounds of biochemical interest. The first supplement, which has recently been published, covers 108 compounds not described in the original volume, together with revisions of a few of the earlier specifications (National Academy of Sciences-National Research Council. Publication 719: Specifications and Criteria for Biochemical Compounds, Supplement One. Pp. 178. Washington, D.C.: National Academy of Sciences-National Research Council, 1963. 3.50 dollars). The information supplied includes structural formulæ of the compounds, brief notes of sources and methods of preparation, and some of the physical properties, for example, melting-point, optical density, specific rotation, and paper chromatographic behaviour in different solvents. Information is also given on the impurities likely to be present, methods of assay, stability and methods of storage. There is a short section on enzymes, which is to be much expanded in the future. This new publication almost doubles the purine and pyrimidine section, and the number of compounds under the heading "Lipids" has been increased from 12 up to 57. There is a cumulative index covering the original volume plus the supplement. The supplement and the original volume should certainly be in any biochemistry library. They can both be obtained, in loose-leaf form, from the P'rinting and Publishing Office of the National Academy of Sciences, 2101 Constitution Avenue, N.W., Washington, D.C., 20418.

\section{Field Studies Council}

The number of students attending Field Studies Centres during 1962-63 continued to grow, and, largely as a result of the opening of the seventh centre at Orielton, there was a further increase of 7 per cent. The total number of weeks devoted to study wero 10,290 , distributed. as follows: (1) biological subjects, 5,532 ; (2) countryside and natural history subjects, 282; (3) geographical and geological subjects, 3,807 ; (4) art, 231 ; (5) archæology, 221 ; (6) other courses, 217. The number of students attending the Centres during this timo was 10,187 , subdivided into the following categories: $(A)$ sixth forms, 6,$187 ;(B)$ other forms, $251 ;(C)$ training colleges and teacher courses, 1,361 ; $(D)$ universities, 1,353 ; $(E)$ technical colleges, $179 ;(F)$ amatours, 856 . Full details of the Council's activities and reports on the individual centres are given in the annual report for 1962-63 (Pp. $35+5$ photographs. London: Field Studies Council, 9 Devereux Court, W.C.2, 1964).

\section{The Scottish Epilepsy Association}

THE Scottish Epilepsy Association had its beginnings as a voluntary association set up in Glasgow in 1950 and worked for a period as a branch of the British Epilepsy Association. In 1954 the Scottish Epilopsy Association was established as an autonomous body. The objects of the Association are to provide welfaro sorvices for the epileptic and for his family; to provide sheltorod workshops for training and employment; to help the general public to a bettor understanding of epilepsy with the view of dispolling the prejudices rangod against epileptics; to sponsor and encourage rosearch into the causes and treatment of epilopsy and to stimulate medical and medico-social rosearch; to maintain international contacts in order to promote mutual bonefit by exchange of views and experience. Details of the way these objects aro being met are described in tho eighth annual report for 1961-62 (Pp. 38. Glasgow: Scottish Epilepsy Association, 1964).

\section{Geological Research in Africa}

IN recent years there has been a marked increase in the amount of geological research being carried out in Africa from British universities. In future, this trend is likely to continue, and, moreover, since in newly independont African States most of the resources available for geological work must of necessity be used for projects of immediate economic potential, an increasing proportion of fundamental research and basic mapping will have to be tackled by politically and financially independent outside bodies. In view of this situation, the symposium which was held at the University of Leeds during March 12-14 was designed to attract a large proportion of the British-based geologists, and allied scientists working in Africa, in order that they should meet one another, discuss common problems and interests and explore the possibilities of effecting some co-ordination of their programmes. The seventy members of the symposium, who included Dr. L. Cahen, director of the Musée Royal de l'Afriquo Centrale, attended a series of scientific sessions covering a wide range of fields of interest, in which the stress was laid on summarizing work in progress rather than on presenting final results. Seven speakers discussed problems in Precambrian rocks, ranging over tho whole of the continent. Further talks were given on alkaline complexes in East Africa, on mineralization in southern Africa and on the application of geochronology, photogeology and geochemistry to African problems. At the genoral moeting which concluded tho symposium, it was suggested that further symposia should be held at regular intervals, and that the heads of the larger research teams should jointly consider the possibility of forming a committeo to formulate policy concerning British university research in Africa.

\section{Chemical Analyses of Australian Rocks}

A COLLECTION of about 3,200 chemical analyses of igneous and metamorphic rocks of Australia, compiled by Dr. Germaine A. Joplin of the Department of Geophysics, Australian National University, has been published by the Bureau of Mineral Resources, Geology and Geophysics, Canberra (Bulletin No. 65: Chemical Analyses of Australian Rocks. Part I: Igneous and Metamorphic. Pp. 446. Canberra City, A.C.T.: Department of National Development, Bureau of Mineral Resources, Geology and Geophysics, 1963). The analyses are arranged lithologically, with an index of rock names, an extensive index of localitios, and a bibliography of 602 references. Although some of the older information included because of its historical interest is incomplete and unreliable, this forms but a small fraction of the whole, and the Bulletin can be claimed to be the largest compilation of its kind available for any country of the British Commonwealth. Petrologists and geochemists alike will bo grateful for the caro and clarity with which the data have been presented. A companion volume (Part II) on the chemistry of Australian sedimentary rocks is in preparation.

\section{The Rigidity of the Earth}

Geophysicrsis have had much cause to be indebted to the Royal Astronomical Society for the support and encouragement which that Society has given to the investigation of the Earth sciences. This indebtedness has been further increased by the foundation and endowment by the Society of the Harold Jeffreys lectureship, the lectures to bo given on geophysical subjects. The endowment was made possible by the procecds of the volume issued by the Soriety to mark the seventieth birthday of Sir Harold Jeffreys. It gave his friends much pleasure that Sir Harold agreed to deliver the first, lecture, at Burlington House on October 25, 1963, under the title "How Soft is the Earth ?". The lecture has now been published (Quart. J. Roy. Astro. Soc., 5, No. 1, 10; 1964). Sir Harold dealt with tidal friction, the formation of 